\title{
ECONOMIC CHARACTERISTICS OF CONCRETE PRODUCTION FROM FLY ASH AS A WAY OF LAND RECULTIVATION ${ }^{1}$
}

\author{
Vladislav Zekič, Nedeljko Tica ${ }^{3}$,Dragan Milič́, Zoran Bačkalić
}

\begin{abstract}
Summary
Application of fly ash in the construction industry is particularly significant in the terms of environmental protection and in the terms of improvement opportunities of certain properties of cement mortar and concrete. In addition to this, it is possible to perform the recultivation of significant area of agricultural land. Concrete production precedes the production of lightweight aggregate which is then used as an aggregate. Calculated costs of concrete production using lightweight aggregate were $70.52 \mathrm{\epsilon} / \mathrm{m}^{3}$. Most of these costs are energy costs in the sum of $85 \%$ of total costs. In the situation when the costs of concrete production using lightweight aggregate are compared to the concrete price at the market, or produced with the use of construction gravel, estimation of the economic viability gives a negative result. This result is caused by the high cost of the aggregate. The observed calculation did not include an improved thermal-insulating property of concrete and reduce pollution through binding of waste ash. According to this, final assessment can only be made after extensive technological, macroeconomic and environmental analysis. Economic analysis should be primarily based on the value of land that can be recultivation in this way.
\end{abstract}

Key words: fly ash, agriculture land, recultivation, concrete production.

JEL: Q32, $R 51$

1 This research was financed by the Ministry of Education, Science and Technological Development of the Republic of Serbia, within the project No. 45008 - Development and implementation of multifunctional material based on domestic raw-material and through modernization of traditional technologies.

2 Vladislav Zekić, Ph.D., Associate Professor, University of Novi Sad, Faculty of Agriculture, Trg Dositeja Obradovića 8, 21000 Novi Sad, Serbia, Phone: +381 633340 890, E-mail: zekic@polj.uns.ac.rs

3 Nedeljko Tica, Ph.D., Full Professor, University of Novi Sad, Faculty of Agriculture, Trg Dositeja Obradovića 8, 21000 Novi Sad, Serbia, Phone: +381 2148533 84, E-mail: tica@polj.uns.ac.rs

4 Dragan Milić, M.Sc., Assistant, University of Novi Sad, Faculty of Agriculture, Trg Dositeja Obradovića 8, 21000 Novi Sad, Serbia, Phone: +381 2148535 10, E-mail: mdragan@polj.uns.ac.rs

5 Zoran Bačkalić, Nexe, Novi Bečej, Serbia, Phone: +381 6489940 52, E-mail: zbackalic@gmail.com

EP 2014 (61) 1 (63-71) 


\section{Introduction}

The main limiting factor in the development of human society is the reduction of reserves of non-renewable mineral resources and energy, where agricultural land is particularly important. Land is one of the most important natural resource. Plants which were bred on agricultural land are transforming solar energy into food and raw materials. In addition, preservation of soil to protect genetic resources and all forms of life on our planet purify and detoxify the water. The land is in the interaction with the atmosphere through absorption and broadcasting in gaseous and solid state. Land Conservation provides essential habitat for humans, plants and animals and contributes functioning and stability of the food chain. In this way, it protects the diversity of life, affecting the global cycles and balance on Earth (Hadžić et al, 2002). Land users, policy makers and the research community, can foster perceptions that degradation of land is the problem that does not directly apply to them (Dalal Clayton, Bass, 2009).

This leads to the development of environmental awareness on a global level, although this is not yet sufficient to achieve a significant impact on the objectives of development, which are still determined by the need for constant growth in consumption. Better knowledge of the change of living environment, with the climate change as most significant, leads to the concern of humankind over the issue of their survival. The modern lifestyle requires a large amount of easily available and cheap energy. A significant part of the environmental problems is related to the construction, maintenance and use of facilities. According to estimates, about $50 \%$ of the total energy produced is consumed in residential and commercial buildings. Of that, $69 \%$ of the energy is consumed in temperature maintaining and ventilation, $15 \%$ for water heating, the lighting and electrical devices about $11 \%$ and $5 \%$ for cooking. The largest emitters of greenhouse gases are the United States and China. Whereas the U.S. comprises $5 \%$ of the world population, but currently spend about $26 \%$ of the total energy. The growth of China argues its high percentage of emissions through its recent industrial development, and while other countries developed and polluted, they were not big emitters. China and the overall Asia are currently in an economic expansion, but also turning to the production system for the use of renewable energy sources, in order to be competitive and participate in the global market (http://esttp.org/cms). In China large amount of construction sites, leads to the deterioration of land resources and other environmental problems (Gar On Yeh, Li, 1999).

Proper management of the construction industry is of great importance since it consumes $60 \%$ of the raw material extracted from the lithosphere, and the construction goes $24 \%$ of a given amount (Wadel, 2009). In addition, previous studies have shown that the construction industry has to uphold sustainability in a great extent and to always take into account the impact on the environment (Speth, 1990; Ehrlich, Ehrlich, 1990) especially when it comes to the destruction of agricultural land.

Amounts of fly ash generated by burning coal in power plants are both in the world and in Serbia, serious economic but primarily environmental problem. Amount of ash that is deposited annually is measured in millions of tones. In Serbia every year occur between 6 and 7 million tons of fly ash. Fly ash landfill covers significant areas of arable land, 
about 1800 ha (http://www.eps.rs/ ecology/zastita.htm). Currently in Serbia, as well as in the world, only a portion of the produced fly ash is used as a pozzolanic additive in cement and concrete (Ilić et al., 2003). Exploitation of this waste as secondary raw materials in the production process imposed as the only viable solution. It is clear that such large quantities of fly ash can only be used in the construction and building materials industry (Baščarević et al., 2006).

\section{Material and methods}

Analysis of the economic characteristics of the plant for the production of concrete is based on the calculation of the investment. It is performed on the basis of the preliminary technical - technological project. Since it is not possible to determine the market price of the lightweight aggregate, costs of production are used in the calculation (Zekić, Bačkalić, 2013). Cost calculation is based on determining the total cost (Jakovčević, 2008). Amortization is calculated in accordance with the estimated investment and superior shelf life of certain assets. Salaries were calculated according to the average wage in the Republic of Serbia, in accordance with the required qualifications. The costs of consumed energy are determined in accordance with the pending charges and market prices. The cost of maintaining the facilities and equipment are accounted by empirical standards. The opportunity cost of financing and land use and insurance costs are not calculated.

\section{Results and discussion}

The scientific understanding and prevention of the land degradation in the past are based on understanding institutional, sectoral, financial, legal and scientific obstacles. On the other hand, it is clear that the degradation of agricultural land is an obstacle to the creation of the sustainable development of society. The solution to these problems includes several sectors and disciplines (Akhtar Schuster et al, 2011).

Construction industry is greatly responsible of land degradation. The problem of preservation and reclamation of agricultural land must be viewed through the development of sustainable technologies in the production of building materials. Land degradation cannot be judged separately of its economic, environmental and cultural context (Warren, 2002).

Concrete is the most widely used construction material. Concrete is a construction material that is made of cement, aggregate or gravel and sand and water. The term "concrete" means a broad range of artificial construction materials of the composite type which are obtained by agglomeration of the different types of grain aggregates. Undoubtedly, widest application has concrete where the cement is used as a binder. Concrete is a material that is the most used of all artificial materials in the world. It is used for making roads, building, foundations, bridges, blocks, etc. Using waste materials in concrete production can reduce the currently very prominent problem of waste. One of the potentially reusable wastes is fly ash from power plants. During the combustion of ground coal in boilers of thermal power plants, ash particles that come along with the flue gases are collected in electrostatic filters. This is called a fly ash and represents approximately $85 \%$ of the total amount of ash in thermal 
power plants. Fly ash has specific characteristics that are significantly different from other industrial by-products used as additives in the cement industry. Beside this, variations of these characteristics are much higher than, for example, of the blast furnaces or filter $\mathrm{SiO} 2$ dust, because they depend on the type and quality of used coal and technological conditions of burning (temperature) and cooling mode of fly ash particles (Baščarević et al., 2006). World production of fly ash is about 700 million tons per year, while only $6 \%$ of this waste material is used in the production of cement (Jozić, 2007; Wong et al., 2004) while the remaining disposed with almost irreversible destruction of agricultural land. In addition, it is used for roads, as a fraction of the support layer, making building bricks, ceramics, glass ceramics and tiles and for the stabilization and solidification of industrial waste (Jovanović et al., 2006). Amounts of ash in this way consumed are insufficient for a permanent solution to the problem of ash landfills so that in each case it is necessary to look for a new ways of use so the use of fly ash as a construction material should be the primary purpose.

The selection of construction materials for certain purposes, as a rule, is carried out on the basis of the functional, technical and financial size. However, the introduction of the concept of sustainability and sustainable development as well as decision-making criteria in the past few decades changed the classical approach to the evaluation of building materials.

Wide application of fly ash as a raw material for the production of building materials, in addition to the above mentioned benefits, to some extent could influence the reduction of unemployment in rural areas where the landfill of ash is typically found. The unemployment problem in the past was latent and concealed within social enterprises and family farms. Today, changes in the social system and the ownership structure of the economy make unemployment prominent problem. The answer to the problem of unemployment among the rural regions is necessary to find in the specific form of rural development (Zekić, Ranogajec, 2012).

Economic analysis of concrete production involves the use of lightweight aggregate which should gain concrete with improved thermal insulation properties (Zekić, Bačkalić, 2013). Concrete production is based on the composition and cost of materials required for making of concrete brand 20 given in the following table.

Table 1. Cost calculation of materials for making concrete brand 20

\begin{tabular}{|l|c|c|c|c|}
\hline \multicolumn{1}{|c|}{ Description } & Quantity & Unit & Price (€/unit) & Value (€) \\
\hline Aggregate & 1,35 & $\mathrm{~m}^{3}$ & 70,52 & 95,20 \\
\hline Cement & 0,3 & $\mathrm{t}$ & 89,00 & 26,70 \\
\hline Water & 0,18 & $\mathrm{~m}^{3}$ & 0,74 & 0,13 \\
\hline Total & & & & $\mathbf{1 2 2 , 0 3}$ \\
\hline
\end{tabular}

Source: calculation by authors

In addition, the cost calculation of material is also performed for the concrete brand 30 and it is shown in the following table. 
Table 2. Cost calculation of materials for making concrete brand 30

\begin{tabular}{|l|c|c|c|c|}
\hline \multicolumn{1}{|c|}{ Description } & Quantity & Unit & Price (€/unit) & Value (€) \\
\hline Aggregate & 1,35 & $\mathrm{~m}^{3}$ & 70,52 & 92,73 \\
\hline Cement & 0,335 & $\mathrm{t}$ & 89,00 & 29,82 \\
\hline Water & 0,18 & $\mathrm{~m}^{3}$ & 0,74 & 0,13 \\
\hline Total & & & & $\mathbf{1 2 2 , 6 8}$ \\
\hline
\end{tabular}

Source: calculation by authors

In line with the aim of research is projected plant for the production of concrete using lightweight aggregate with capacity of $80 \mathrm{t} / \mathrm{h}$. Total investment in the plant for the production of concrete is approximately 2.6 million $€$, of which 1.45 million $€$ is for equipment, while 1.15 million $€$ makes investments in facilities and utility equipment. The calculation of amortization costs is shown in the following table.

Table 3. Calculation of amortization costs $(€)$

\begin{tabular}{|l|c|c|c|}
\hline \multicolumn{1}{|c|}{ Description } & Value & Rate & Amount \\
\hline Facilities and utility equipment & $1.150 .000,00$ & $2,50 \%$ & $28.750,00$ \\
\hline Equipment & $1.450 .000,00$ & $8,00 \%$ & $116.000,00$ \\
\hline Total & $\mathbf{2 . 6 0 0 . 0 0 0 , 0 0}$ & & $\mathbf{1 4 4 . 7 5 0 , 0 0}$ \\
\hline
\end{tabular}

Source: calculation by authors

An estimation of the observed technology can be made only by a complete investment analysis. Only in this way it is possible to reach the value of investments that an investor can invest in a given plant, or costs of production that can be covered by the revenues.

Plan of the plant work is based on the duration of the shift from $7.30 \mathrm{~h}$, six working days a week, two production shifts per day. The plan includes one shift a week for overhaul. In accordance with this, plan includes 11 production shifts per week and fifty working weeks in a year. Calculation of costs for salaries plans constantly engaging 9 people. The calculation of salary costs is shown in the following table.

Table 4. Calculation of salary costs $(€)$

\begin{tabular}{|l|r|r|r|r|}
\hline \multicolumn{1}{|c|}{ Description } & \multicolumn{1}{c|}{$\begin{array}{c}\text { Number of } \\
\text { employees }\end{array}$} & Net salary & Gross salary & \multicolumn{1}{c|}{ Total } \\
\hline Production manager & 1 & 600 & 990 & $11.880,00$ \\
\hline Manager & 2 & 500 & 825 & $9.900,00$ \\
\hline Workers & 6 & 500 & 825 & $9.900,00$ \\
\hline Total & $\mathbf{9}$ & & & $\mathbf{3 1 . 6 8 0 , 0 0}$ \\
\hline
\end{tabular}

Source: calculation by authors

Consumptions of raw materials and energy are calculated on an annual output of 33,000 tons of aggregates. Planned specific power consumption $1.1 \mathrm{kWh} / \mathrm{t}$. Water consumption is $0,18 \mathrm{~m}^{3} / \mathrm{t}$. The calculation of production costs is shown in the following table. 
Table 5. Calculation of concrete production $(€)$

\begin{tabular}{|l|c|c|}
\hline \multirow{2}{*}{ Description } & \multicolumn{2}{|c|}{ Type of concrete } \\
\cline { 2 - 3 } & MB 20 & MB 30 \\
\hline Material & 122,03 & 122,68 \\
\hline Aggregate & 95,20 & 92,73 \\
\hline Cement & 26,70 & 29,82 \\
\hline Water & 0,13 & 0,13 \\
\hline Amortization & 0,44 & 0,44 \\
\hline Salary & 0,10 & 0,10 \\
\hline Maintenance & 0,16 & 0,16 \\
\hline Costs of energy & 0,12 & 0,12 \\
\hline Other costs & 0,10 & 0,10 \\
\hline Total costs & $\mathbf{1 2 2 , 9 5}$ & $\mathbf{1 2 3 , 5 9}$ \\
\hline Sale price & 52,00 & 58,00 \\
\hline Result & $\mathbf{- 7 0 , 9 5}$ & $\mathbf{- 6 5 , 5 9}$ \\
\hline
\end{tabular}

Source: calculation by authors

The total planned production is $33.000 \mathrm{~m} 3$. Based on the planned production and actual expenses can be derived basic economic indicators. The amount of calculated costs of concrete production using lightweight aggregate are 122.95 or $123.59 € / \mathrm{m}^{3}$. In doing so, most of the costs are the costs of materials, which in the sum are over $99 \%$ of total costs. In the situation when the costs of concrete production using lightweight aggregate are compared to the concrete price at the market, or produced with the use of construction gravel, estimation of the economic viability gives a negative result. This result is caused by the high price of used units. Price of construction gravel on the market is $18.00 € / t$, which is much lower compared to the lightweight aggregates.

\section{Conclusion}

One of the ways to ensure the preservation of the environment is to use materials that are by-products of energy production, as aggregate for mortar and concrete. The use of waste materials not only affects the reduction of environmental pollution, but also has an impact on society resources conservation, because it reduces the exploitation of raw materials and provides a substitute for materials like cement, whose manufacture requires significant amounts of raw materials, energy and resources to produce.

The use of fly ash as a raw material for the production of building materials has a number of advantages: 1) permanently solves the problem of waste and the deterioration of agricultural land, 2) reduces the depletion of other natural resources, 3) creates a basis for energy efficiency through substitution of cement, 4) the recycling process is flexible since the waste can be easily stored and used for several purposes. Therefore, the use of fly ash in building materials and concrete technology solves the problems of industrial waste, environment pollution, the destruction of thousands of acres of land. In doing so, it also offers the possibility of creating new cost-effective building materials. In addition, the economic results should be interpreted bearing in mind that the calculations are evaluated 
using the possible recultivation of agricultural land. The consequences of certain types of land degradation can be catastrophic if we forget that the land is one of the most important and irreplaceable resource on earth. Environmental sustainability puts agricultural land at the centre of any development strategy. For this reason, conservation, protection and rational use of agricultural land should be at the centre of any development strategy. There is an urgent need to solve this problem, bearing in mind the trends in increasing land degradation and its links with climate change, biodiversity loss, poverty, health, food, water and energy and general uncertainty.

The production costs of concrete obtained with the use of lightweight aggregates is significantly higher than the current market price. In accordance with this, current application of concrete the produced in the described manner is not economical. During this assessment it is necessary to bear in mind that the calculation did not include the observed enhanced thermal-insulating properties of concrete and pollution reduction through binding of fly ash. In accordance with this final assessment can only be made after extensive technological and macroeconomic analysis.

\section{Literature}

1. Akhtar Schuster, M., Thomas, R. J., Stringer, L. C., Chasek, P., Seely, M. (2011): Improving the enabling environment to combat land degradation: Institutional, financial, legal and science-policy challenges and solutions, Land Degradation \& Development, Special Issue, Vol. 22, Issue 2, March/April 2011, pp. 299-312.

2. Baščarević, Z., Komljenović, M., Petrašinović Stojkanović, L., Jovanović, N., Rosić, A., Ršumović, M. (2006): Ispitivanje svojstava elektro-filterskog pepela termoelektrana u cilju njegove upotrebe kao sekundarne sirovine za proizvodnju portland-cementnog klinkera, Hemijska industrija, vol. 60(9-10), pp. 245-252.

3. Dalal Clayton, B., Bass, S. (2009): The challenges of environmental mainstreaming: Experiences of integrating environment into development institutions and decisions, IIED, available at: http:/www.iied.org/pubs/pdfs/17504IIED.pdf

4. Ehrlich, P., Ehrlich, A. (1990): The population explosion, London, UK, Hutchinson.

5. Gar On Yeh, A., Li, X., (1999): Economic Development and Agricultural Land Loss in the Pearl River Delta, China, Habitat International, vol. 23, no. 3, pp. 373-390.

6. Hadžić, B., Nešić, M., Belić, M., Furman, T., Savin, L. (2002): Zemljišni potencijal Srbije, Traktori i pogonske mašine, vol. 7(5), pp. 43-51.

7. Ilic, M., Cheeseman, C., Sollars, C., Knight, J. (2003): Mineralogy and microstructure of sintered lignite coal fly ash, Fuel, vol. 82, pp. 331-336.

8. Jakovčević, K. (2008): Upravljanje troškovima, Ekonomski fakultet Subotica.

9. Jovanović, M., Bošnjak, D., Zekić, V. (2004): Ekonomska analiza proizvodnje biodizela, Ekonomika poljoporivrede, spec. br., Poljoprivredni fakulteta u Zemunu, Beograd, pp. $127-138$. 
10. Jozić, D. (2007): Studija utjecaja letećeg pepela iz termoelektrane na fizikalno-kemijska svojstva i ponašanje cementnog kompozita, Doktorska disertacija, Kemijsko-tehnološki fakultet, Split, Srpanj 2007.

11. Speth, J. G. (1990): Can the world be saved?, Ecol Econom 1990, no. 1, pp. 289-302.

12.Zekić, V., Bačkalić, Z. (2013): Economics characteristics of production of lightweight aggregates from waste materials, International Scientific Conference Sustainable agriculture and rural development in terms of the Republic of Serbia strategic goals realization within the Danube region, thematic proceedings, IAE Belgrade, pp. 729-745.

13.Zekić, V., Ranogajec, J. (2012): Production of the traditional building material as an element of rural development, Sustainable Agriculture and Rural Development in Terms of The Republic of Serbia Strategic Goals Realization within The Danube Region (preservation of rural values), Thematic proceedings, IAE Belgrade, pp. 713-729.

14. Wadel, G. (2009): Sustainability in industrialized architecture: Modular lightweight construction applied to housing (La sostenibilidad en la construcción industrializada. La construcción modular ligera aplicada a la vivienda), Doctoral Thesis, Polytechnic University of Catalonia-Department of Architectural Constructions, Available online at: http://www.tdx.cat/TDX-0122110-180946

15. Warren, A. (2002): Land degradation is contextual, Land Degradation \& Development, Vol. 13, no. 6, November 2002, pp. 449-459.

16. Wong, A., Zhang, C., Sun, W. (2004): Fly ash effects II. The active effect of fly ash, Cement and Concrete Research, vol. 34, pp. 2057-2060. 


\title{
EKONOMSKA OBELEŽJA PROIZVODNJE BETONA IZ ELEKTROFILTERSKOG PEPELA KAO NAČIN ZA REKULTIVACIJU POLJOPRIVREDNOG ZEMLJIŠTA
}

\author{
Vladislav Zekič́, Nedeljko Tica ${ }^{7}$, Dragan Milič ${ }^{8}$,Zoran Bačkalić ${ }^{9}$
}

\begin{abstract}
Rezime
Primena elektrofilterskog pepel u građevinarstvu je pre svega značajna sa aspekta zaštite čovekove okoline i sa aspekta mogućnosti poboljšanja određenih svojstva cementnih maltera $i$ betona. Pored toga moguće je izvršiti rekultivaciju značajne površine poljoprivrednog zemljišta. Proizvodnji betona prethodi proizvodnja lakog agregata koji se potom koristi kao agregat. Obračunati troškovi proizvodnje betona uz korišćenje lakog agregata iznose 70,52 €/ $\mathrm{m}^{3}$. Prilikom toga, najveći deo troškova čine troškovi energije koji u zbiru iznose 85\% ukupnih troškova. U slučaju da se troškovi proizvodnje betona uz korišćenje lakog agregata porede sa cenom betona na komercijalnom tržištu, odnosno proizvedenog uz korišćenje građevinskog šljunka, ocena ekonomske isplativosti daje negativan rezultat. Navedeni rezultat je uslovljen visokim troškovima agregata. Posmatrani obračun nije uključio poboljšane termoizolacione osobine betona i smanjenje zagađenja kroz vezivanje otpadnog elektrofilterskog peska. U skladu sa time konačnu ocenu moguće je dati tek posle opsežne tehnološke, makroekonomske i ekološke analize. Prilikom toga ekonomska analiza prvenstveno treba da se bazira na vrednosti zemljišta koje je moguće rekultivirati na ovaj način.
\end{abstract}

Ključne reči: elektrofilterski pepeo, poljoprivredno zemljište, rekultivacija, proizvodnja betona.

6 Dr Vladislav Zekić, vanredni profesor, Univerzitet u Novom Sadu, Poljoprivredni fakultet, Trg Dositeja Obradovića 8, 21000 Novi Sad, Srbija, Telefon: +381 633340 890,E-mail: zekic@polj.uns.ac.rs

7 Dr Nedeljko Tica, redovni profesor, Univerzitet u Novom Sadu, Poljoprivredni fakultet, Trg Dositeja Obradovića 8, 21000 Novi Sad, Srbija, Telefon: +381 2148533 84,E-mail: tica@polj.uns.ac.rs

8 Mr Dragan Milić, asistent, Univerzitet u Novom Sadu, Poljoprivredni fakultet, Trg Dositeja Obradovića 8, 21000 Novi Sad, Srbija, Telefon: +381 2148535 10, E-mail: mdragan@polj.uns.ac.rs

9 Zoran Bačkalić, Nexe, Novi Bečej, Srbija, Telefon: +381 6489940 52, E-mail: zbackalic@gmail.com

EP 2014 (61) 1 (63-71) 
